\title{
Transfer Ladle Tracking System Using Wireless Sensor Network
}

\author{
Meriç Işı1 ${ }^{1^{*}}$, Özlem Karaca Akkan ${ }^{2}$ \\ 1* R\&D Center, CMS Jant ve Makina San. A.Ş. İzmir, Turkey, (ORCID: 0000-0002-6612-5717), misik@ cms.com.tr \\ ${ }^{2}$ Dokuz Eylül University, Izmir Vocational School, Telecommunication Programme, İzmir, Turkey, (ORCID: 0000-0003-1781-6375), ozlem.karaca@deu.edu.tr
}

(First received 30 April 2021 and in final form 16 December 2021)

(DOI: 10.31590/ejosat.930463)

ATIF/REFERENCE: Işık, M., Karaca Akkan, Ö. (2021). Transfer Ladle Tracking System Using Wireless Sensor Network. European Journal of Science and Technology, (31), 205-211.

\begin{abstract}
Process optimization is one of the most important steps in improvement. Data need to be collected and evaluated to improve a process, reduce non-value-added time and make the process more efficient. Within the scope of the study, the foundry of a company that produces passenger car wheels using low pressure casting method is theoretically modified with a sensor network containing RFID and ZigBee, thermocouple and wireless forklift scale. Problems that may be encountered while establishing the sensor network are anticipated and solution suggestions are presented.
\end{abstract}

Keywords: Sensor network, RFID, ZigBee, Communication protocol.

\section{Kablosuz Sensör Ă̆g ile Transfer Potası Takibi}

$\ddot{O} \mathbf{z}$

Süreç optimizasyonu, iyileştirmenin en önemli adımlarından biridir. Bir süreci iyileştirmek, katma değersiz zamanı azaltmak ve süreci daha verimli hale getirmek için verilerin toplanması ve değerlendirilmesi gerekir. Çalışma kapsamında, alçak basınçlı döküm yöntemi ile binek otomobil jantları üreten bir firmanın dökümhanesi, RFID, ZigBee, termokupl ve kablosuz forklift çatal kantarı içeren bir sensor ağı ile teorik olarak modifiye edilmiştir. Sensör ağı kurulurken karşılaşılabilecek sorunlar öngrülerek çözüm önerileri sunulmuştur.

Anahtar Kelimeler: Sensör ağı, RFID, ZigBee, İletişim protokolü.

\footnotetext{
* Corresponding Author: misik@ cms.com.tr
} 


\section{Introduction}

In order for a process to be optimized, the process steps must first be determined and defined clearly. The collection of data which is the inputs of the process steps, is of great importance in terms of optimization. After the data is collected, process analysis is performed to determine non-value-added times and studies that can increase process efficiency are carried out.

Within the scope of the study, it is aimed to follow the transfer ladle in a foundry by establishing a sensor network. Transfer ladle and forklift tracking is a widely studied topic in the industry. A wide variety of sensor networks, sensors, data collection methods are used on the subject.

The second chapter includes a comprehensive literature review. In the third chapter, the current transfer system used in the foundry is explained. In the fourth chapter, tools and protocols used in system optimization are mentioned. The optimized transfer pot tracking system is explained in detail in the fifth chapter.

\section{Literature Review}

In this chapter, literature research on wireless ladle transfer systems is mentioned.

In the study in which the cast iron ladle is followed, $\mathrm{Wu}$ et al. carried out the ladle tracking using a combination of ZigBee and image processing methods. In the study, the overhead traveling crane system is followed by ZigBee. With image processing, the number of the ladle carried by the crane is read and the position accuracy is checked. Test results show that the position of the ladles can be measured with $2 \mathrm{~m}$ accuracy. The accuracy rate of the position tracking of the ladles is $97.34 \%$ (Wu et al. 2018).

Zhou et al have used RFID and WLAN technology in the tracking of iron and steel casting ladles. In order to optimize the number of ladles, data is collected from the foundry environment. These data are analyzed with the queuing theory methods and the appropriate number of ladles is determined. In the installed system, the location of the ladles is detected by RFID sensors. Communication between the ladles and the main control room is established by WLAN (Zhou et al. 2019).

Most of the quality problems experienced in a foundry often occur due to the chemical composition or the wrong casting process. In order to eliminate the problems causing chemical problems, the weight of the ladle is measured by the load cell and the position of the ladle is tracked by RFID systems. The optimization of the transfer and alloying process is achieved with the information of ladle positions and weight data. As a result of the study, stable chemical composition is obtained in the foundry (Singh et al. 2020).

In a foundry, ladle tracking is carried out and the transfer process is optimized by Ahualli et al (2014). Ladle tracking is provided by passive RFID tags attached to the ladles. Problems such as RFID tags not functioning are encountered due to the excess of metal in the environment and the high surface temperature that affects the operation of the RFID tag. The problem is overcome by creating a compartment for the RFID tag on the ladle.
In a patent study, Donald et al. developed a system that measures the weight of the transfer ladle while transporting the metal from one point to another. The system consists of load cells integrated into critical areas of the ladle transfer car. With the method based on theoretical calculation, transfer ladle weights can be measured on the car while transporting (Watkins et al. 1998).

\section{Current Ladle Transfer System}

In this section, the ladle transfer process carried out in the foundry of the factory is explained. The current situation analysis carried out and the potential points for improvement have been determined.

One of the most important points of production efficiency is planning. Process stabilization is achieved by transferring the appropriate raw material to the casting benches on time. The planning process which has a direct impact on product quality, is currently carried out depending on the operators. The disadvantages of the current situation are listed below.

- The follow-up of the transfer of metal from the melting furnaces to the casting benches depends on the operators.

- Failure to determine the non-value-added time that occurs during transfers.

- Inability to make instant workforce planning, uncertainty of working with more or less operators.

- The problem of molten metal cooling during transfer and its effects on the casting process as disruptive input.

- The amount of metal in the transfer ladle is under the control of the operator.

- The metal level in the casting bench decreases due to the prolongation of the transfer ladle waiting time.

During a metal transfer cycle, molten metal is fed to four casting benches with the transfer ladle (Fig. 1). Since there are 72 casting benches in total, 18 transfers are required to transfer metal to all casting benches. The transfer process is done 6 times per shift. A total of 324 transfers per day are made in the factory, which has a 3-shift system.

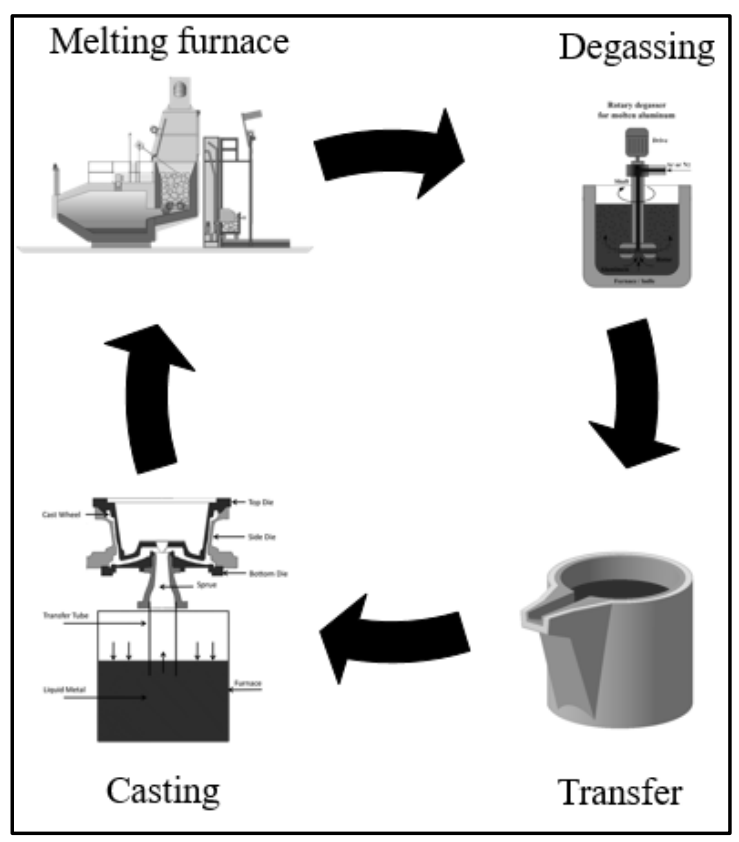

Figure 1. Transfer cycle. 
22 ladle transfers were examined in order to perform the current situation analysis. Theoretical and actual metal temperatures, transfer times data were collected. The normal distribution of the data was evaluated by statistical analysis. Normal distribution is a term that indicates the ability of a population sample to represent the population. If a data is distributed normally, the sample represents the population. $\mathrm{P}$ values greater than 0.05 indicate that the data show a normal distribution (Iş1k, 2019). It was determined that the collected transfer process data were distributed normally (Fig. 2). After determining that the data were distributed normally, the current situation analysis was carried out (Table 1). The losses were analyzed separately for each step (Fig. 3). During the calculation of the losses, the heat energy formula was used. The amount of energy lost was determined and its financial equivalent was calculated. The annual average financial loss has been determined as 210266 TL.

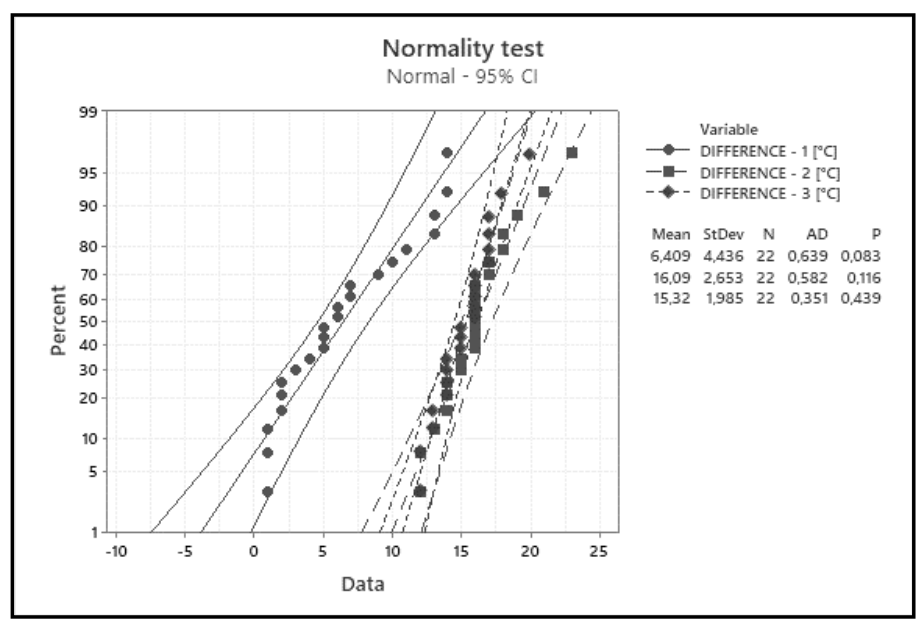

Figure 2. Normality test of collected data.

Heat energy formula (Eq. 1) is used to calculate the amount of heat loss during transfers.

$$
Q=m c \Delta T
$$

- Q: Heat energy $[\mathrm{J}]$ or $[\mathrm{kWh}]$

- m: Mass [kg]

- c: Specific Heat $\left[\mathrm{J}^{\circ} \mathrm{C}-1 \mathrm{~kg}-1\right]$

- $\Delta \mathrm{T}$ : Change in temperature $\left[{ }^{\circ} \mathrm{C}\right]$

Loss cost formula is derived from heat energy to calculate the financial loss. The coefficient may vary depending on the time and country (Eq. 2).

$$
L=Q \cdot n
$$

- L: Loss cost [TRY]

- Q: Heat energy [kWh]

- n: Natural gas cost [TRY/kWh] (February, 2021, Izmir, Turkey Natural Gas Prices used).

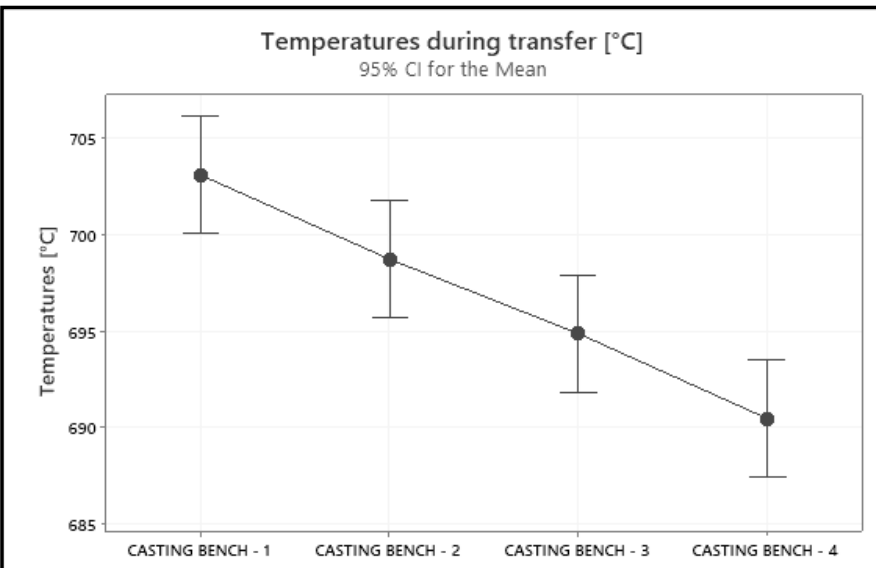

The pooled standard deviation is used to calculate the intervals.

Figure 3. Means of the temperatures of the molten metal fed to the casting benches. (Statistically significant differences between means $(\mathrm{P}<0.05))$

\section{Used Communication Protocols and Modules}

It is planned to use Modbus RTU, RS-485, ZigBee, RFID, thermocouple and load cell in the ladle transfer system developed. Communication protocols and details of modules are given in the following subsections.

\subsection{Modbus RTU}

Modbus is one of the most widely used industrial communications protocols in industrial control applications. Modbus Remote Terminal Unit (RTU) is point to point open serial communication protocol. It is used to develop communication between intelligent devices (Urrea et al. 2016). Modbus RTU protocol works in the data layer, which is the second layer of the OSI (Open System Interconnection) model (Guarese et al. 2012).

Advantages

- It has been developed for industry applications.

- It has been published openly and is not subject to many fee.

- It is easy to install and maintain.

Limitations

- The Modbus protocol was programmed in the 1970s. Therefore, the technological constraints of the time have been carried to the present day.

- Modbus is limited to addressing 247 devices in one data link

- Modbus protocol does not contain measures taken against security problems.

\subsection{RS-485}

RS-485 is a serial communication standard developed for using in long distances, noisy environments, places requiring higher speed and where more transceivers are required. Network topology of the RS 485 is point to point, multi-dropped or multipoint. Devices can be located up to 1200 meters away without using a repeater. By using RS-485, up to 32 devices can be connected (Int Ref. 1). 
Table. 1 Due Diligence

\begin{tabular}{|c|c|c|c|c|}
\hline Variable & Mean & StDev & Minimum & Maximum \\
\hline Estimated Molten Metal [kg] & 1200 & 0 & 1200 & 1200 \\
\hline Theoretical Temperature Before Degassing $\left[{ }^{\circ} \mathrm{C}\right]$ & 728,14 & 6,92 & 715 & 739 \\
\hline Measured Temperature Before Degassing $\left[{ }^{\circ} \mathrm{C}\right]$ & 721,86 & 6,96 & 710 & 733 \\
\hline Energy Loss - $1[\mathrm{~J}]$ & 7248764 & 5083412 & 1155600 & 16178400 \\
\hline Energy Loss - $1[\mathrm{kWh}]$ & 2,014 & 1,412 & 0,321 & 4,494 \\
\hline Loss of Money - 1 [TRY] & 0,296 & 0,2076 & 0,0472 & 0,6606 \\
\hline Measured Temperature After Degassing $\left[{ }^{\circ} \mathrm{C}\right]$ & 705,77 & 6,77 & 693 & 715 \\
\hline Energy Loss - $2[\mathrm{~J}]$ & 18594655 & 3065927 & 13867200 & 26578800 \\
\hline Energy Loss - $2[\mathrm{kWh}]$ & 5,165 & 0,852 & 3,852 & 7,383 \\
\hline Loss Cost - 2 [TRY] & 0,7592 & 0,1252 & 0,5662 & 1,0852 \\
\hline Casting Bench -1 & 703,09 & 6,77 & 689 & 714 \\
\hline Casting Bench -2 & 698,73 & 7,07 & 684 & 709 \\
\hline Casting Bench -3 & 694,86 & 7,24 & 679 & 705 \\
\hline Casting Bench -4 & 690,45 & 7,56 & 676 & 701 \\
\hline Energy Loss - $3[\mathrm{~J}]$ & 17701691 & 2294254 & 13867200 & 23112000 \\
\hline Energy Loss - $3[\mathrm{kWh}]$ & 4,917 & 0,637 & 3,852 & 6,42 \\
\hline Loss Cost - 3 [TRY] & 0,7228 & 0,0937 & 0,5662 & 0,9437 \\
\hline Total Difference $\left[{ }^{\circ} \mathrm{C} /\right.$ transfer $]$ & 37,68 & 5,79 & 30 & 48 \\
\hline Total Energy Loss [kWh/transfer] & 12,096 & 1,86 & 9,63 & 15,408 \\
\hline Total Loss Cost [TRY/transfer] & 1,778 & 0,2733 & 1,4155 & 2,2649 \\
\hline Daily Loss Cost [TRY/Day] & 576,1 & 88,6 & 458,6 & 733,8 \\
\hline Yearly Loss Cost [TRY/Year] & 210266 & 32326 & 167401 & 267842 \\
\hline
\end{tabular}

\section{Advantages}

- RS 485 connectors are designed to protect excessive current flows in order not to be affected by thermal shut down due to heating.

- Noise immunity.

- RS-485 supports single master and multiple slaves.

\section{Limitations}

- Only single node can transmit data at a time.

- Special cable types are used in the RS-485 interface.

- In RS-485, system backup is complex and difficult.

\subsection{ZigBee}

ZigBee is a communications standard which provides a cost-effective, short-range networking solution. Zigbee technology, known as low-speed wireless personal network communication technology (LR-WPAN, Low-Rate Wireless Personal Area Network), is highly preferred in applications that can be realized with small-scale data exchange due to its low cost, minimum power consumption, easy installation and flexible structure. Thanks to this technology, it is possible to establish complex network structures, to expand them and to enable these structures to communicate with other technologies (Safaric \& Malaric, 2006).

Advantages

- Flexible network structure.
- Low power consumption, long battery life

- Self-healing

- Low cost

Limitations

- Short range

- It's not secure like Wi-Fi based secured system.

- Low transmission rate (Int Ref. 2).

\subsection{RFID}

The main feature of RFID system is that they use a wireless channel such as GSM or GPS and they have calculation capabilities like magnetic cards. For all these reasons, more and more attention has been paid to this technology in recent years.

The RFID system uses radio waves to identify and track objects (Table 2). It has a recognition system like other recognition systems like fingerprints, barcodes or iris recognition. An RFID system consists of three main components. The first item is the RFID tag (transponder) that contains the identification data, the second item is the RFID reader (transceiver) that requests an information for the stored data, and the third item is the server that processes the data obtained through the RFID reader (Ozcan, 2019). 
Table 2. RFID Frequency comparison (Doğan, 2016)

\begin{tabular}{|c|c|c|c|c|c|}
\hline \multirow{2}{*}{ Band } & \multirow{2}{*}{$\begin{array}{c}\text { Common } \\
\text { Used Frequency }\end{array}$} & \multirow{2}{*}{ Type of Tag } & \multicolumn{2}{|c|}{$\begin{array}{c}\text { Communication } \\
\text { range }\end{array}$} & \multirow{2}{*}{$\begin{array}{c}\text { Allowed field } \\
\text { strength } \\
\text { transmission } \\
\text { power } \\
\end{array}$} \\
\hline & & & Typical & Max. & \\
\hline LF & $125-134.2 \mathrm{KHz}$ & Passive & $20 \mathrm{~cm}$ & $100 \mathrm{~cm}$ & $72 \mathrm{~dB} \mu \mathrm{A} / \mathrm{m} \max$ \\
\hline HF & $13.56 \mathrm{MHz}$ & $\begin{array}{l}\text { Passive and } \\
\text { semi-passive }\end{array}$ & $10 \mathrm{~cm}$ & $1.5 \mathrm{~m}$ & $60 \mathrm{~dB} \mu \mathrm{A} / \mathrm{m} \max$ \\
\hline \multirow[b]{2}{*}{ UHF } & $433 \mathrm{MHz}$ & Active & $3 \mathrm{~m}$ & $10 \mathrm{~m}$ & $10-100 \mathrm{~mW}$ \\
\hline & 860 and $915 \mathrm{MHz}$ & $\begin{array}{l}\text { Active and } \\
\text { passive }\end{array}$ & $3 \mathrm{~m}$ & $15 \mathrm{~m}$ & $0.1-4 \mathrm{~W}$ \\
\hline Microwave & 2.4 and $5.8 \mathrm{GHz}$ & $\begin{array}{l}\text { Active and } \\
\text { passive }\end{array}$ & $3 \mathrm{~m}$ & $30 \mathrm{~m}$ & $0.5-4 \mathrm{~W}$ \\
\hline
\end{tabular}

Advantages

- Simultaneous automatic reading

- High accuracy

- Labour reduction

- Enhanced visibility and forecasting

\section{Limitations}

- High cost of the system

- Some materials may create signal problem

- $\quad$ Sporadic false negatives/positives (Pakrash et al. 2012)

\subsection{Thermocouple}

Thermocouple is a type of temperature sensor. It consists of two different conductive materials. If the two ends of these materials are joined (hot spot) and heated, voltage is obtained at the other ends (cold spot). The value of this voltage depends on the type of material used and the heating amount of the junction point. The temperature difference between the hot spot and the cold spot creates a voltage (EMF) on the thermocouple. Different temperatures are read when the cold point temperature changes with the condition that the hot spot temperature remains the same. For this reason, the measured temperature equivalent $\mathrm{mV}$ values are obtained by keeping the cold point at $0^{\circ} \mathrm{C}$ in order to provide a standard in the values in the $\mathrm{mV}$ tables. Thermocouples are widely used for measurement and control at various temperatures from $-200^{\circ}$ to $2320^{\circ} \mathrm{C}$ (Int Ref. 3).

Advantages

- Fast response

- Wide temperature range

- Durability

\section{Limitations}

- Vulnerable to corrosion

- Less accurate (than resistance temperature detectors)

\subsection{Load Cell}

A load cell is the converter used to convert a force into an electrical signal. The transformation takes places indirectly and in two stages. With a mechanical arrangement, the perceived force changes the shape of the strain gauge. The strain gauge measures the shape change as an electrical signal. Because, the strain changes the effective electrical resistance of the wire. A load cell usually consists of four strain gauges arranged in a
Wheatstone bridge. There are also quarter bridge or half bridge load cells customized according to their usage areas. The electrical signal read by the load cells is usually in the order of several millivolts. For this reason, the signals must be amplified with an amplifier before being used.

\section{Ladle Tracking System}

The melting furnace, degassing machine, transfer ladle and casting benches, which are the main elements of the metal transfer process, will be made to communicate with each other using the sensor network. With this sensor system, which is the first step of IoT, it is aimed to monitor, record and optimize every step in the process. Information about the ladle tracking process is listed below.

The melting furnace is fed with ingots. The weight of each ingot is standard. Thereby, the amount of metal in the melting furnace will be known in the first step. In the later steps of the process, a theoretical correlation will be established between the amount of metal sent to the casting benches and the number of ingots added to the melting furnace.

- It is planned to use the Modbus RTU communication protocol, by means of its advantages, prevalence and free of charge. The 247 devices limit, which is one of the disadvantages of the Modbus RTU protocol, does not pose a problem because the system to be installed contains fewer devices.

- It is planned to use fire and oil resistant RS-485, which is successful in transmitting data over long distances in noisy environments. It is practical to use in the work area as it provides communication opportunity using only two cables.

- Passive RFID tags will be used in the sensor network. The average temperature of the ladle is around $280^{\circ} \mathrm{C}$ (Fig. 4.). The values in Table 3 are used as input for finite element analysis and an RFID sensor protective pocket is designed. The average surface temperature of the pocket that designed for RFID tag installation is $200{ }^{\circ} \mathrm{C}$ (Fig. 5). Therefore, the RFID tag to be used must be resistant to high temperatures. The suitable operating temperature for RFID tag must be up to $200{ }^{\circ} \mathrm{C}$. However, it should be able to withstand temperatures of $800^{\circ} \mathrm{C}$ for a short time. Reading RFID tags by more than one antenna at the same time causes problems. RFID tag frequencies and ladle routes considered together to determine appropriate antenna locations. The distance will be $1.5 \mathrm{~m}$ between the antennas to be placed around the casting benches and the RFID tag during feeding the casting bench. Therefore, it is appropriate to use $860 \mathrm{MHz}$ RFID devices.

$R_{n}=\frac{\Delta L}{k A}$

$\mathrm{Rn}$ : absolute thermal resistance $\left(\mathrm{W}-1^{\circ} \mathrm{C}\right)$ across the thickness of the sample

$\Delta \mathrm{L}$ : thickness $(\mathrm{m})$ of the sample (measured on a path parallel to the heat flow) $[\mathrm{m}]$

$\mathrm{k}$ : thermal conductivity of the sample $\left[\mathrm{W}^{\circ} \mathrm{C}-1 \mathrm{~m}-1\right]$ 
Table 3. Heat transfer through ladle wall

\begin{tabular}{|c|c|c|c|}
\hline $\mathrm{T}_{1}\left[{ }^{\circ} \mathrm{C}\right]$ & $\mathrm{T}_{2}\left[{ }^{\circ} \mathrm{C}\right]$ & $\mathrm{T}_{3}\left[{ }^{\circ} \mathrm{C}\right]$ & $\mathrm{T}_{4}\left[{ }^{\circ} \mathrm{C}\right]$ \\
\hline 750 & 724 & 295 & 295 \\
\hline $\begin{array}{c}\text { Molten } \\
\text { Metal }\end{array}$ & Refractory & Fiber & $\begin{array}{l}\text { Steel } \\
\text { Shell }\end{array}$ \\
\hline Thickness & $\mathbf{L}_{1}$ & $\mathbf{L}_{2}$ & $\mathbf{L}_{3}$ \\
\hline m & 0,025 & 0,025 & 0,01 \\
\hline Area & $\mathbf{A}_{1}$ & $\mathbf{A}_{2}$ & $\mathbf{A}_{3}$ \\
\hline $\mathbf{m}^{2}$ & 1 & 1 & 1 \\
\hline $\begin{array}{c}\text { Thermal } \\
\text { conductivity }\end{array}$ & $\mathbf{k}_{1}$ & $\mathbf{k}_{2}$ & $\mathbf{k}_{3}$ \\
\hline $\mathrm{W} /\left(\mathbf{m}^{2} \cdot \mathrm{C}\right)$ & 2,5 & 0,153 & 50,0000 \\
\hline $\begin{array}{c}\text { Thermal } \\
\text { resistance }\end{array}$ & $\mathbf{R}_{1}$ & $\mathbf{R}_{2}$ & $\mathbf{R}_{3}$ \\
\hline $\mathrm{m}^{2} \cdot \mathrm{C} / \mathrm{W}$ & 0,0100 & 0,1634 & 0,0002 \\
\hline
\end{tabular}

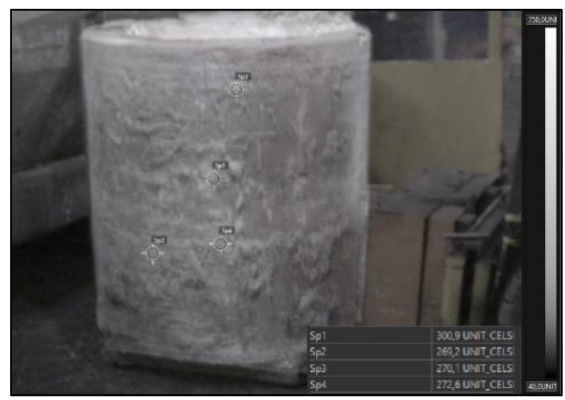

Figure 4. Thermal imaging of the ladle (Emissivity of stainless steel, weathered is 0,79 )

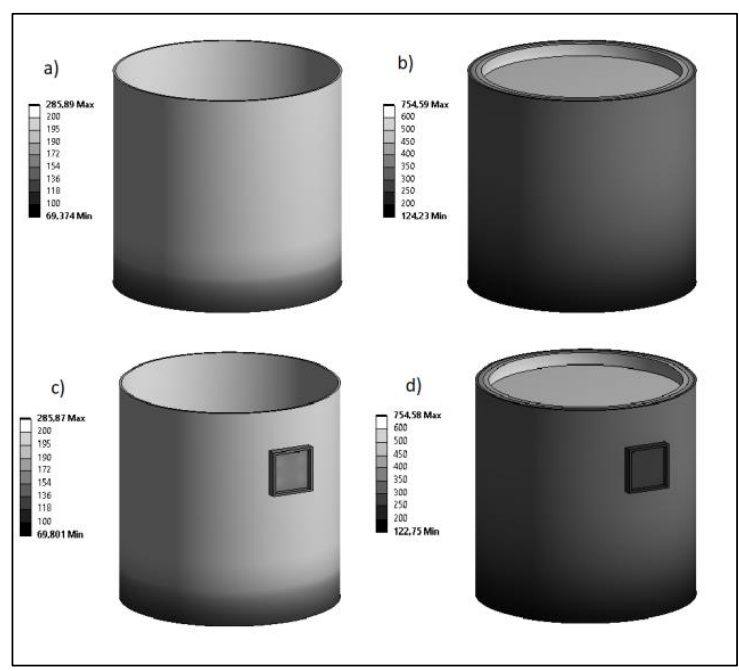

Figure 5. Transient Thermal Analysis of Transfer Ladle, a) Steel shell, b) Whole model, d) Steel shell with pocket, e) Whole model with pocket.

- Each location information read by the antennas must be transmitted to the system center and stored with time, ladle number and temperature stamps.
- The temperature of the molten metal is on average $800{ }^{\circ} \mathrm{C}$. The thermocouple to be used will remain in the molten metal continuously. Therefore, it should not be physically damaged when reading the temperature correctly. K-Type thermocouples operate between $-200{ }^{\circ} \mathrm{C}$ and $1200{ }^{\circ} \mathrm{C}$. It is advantageous to use K-Type thermocouples by means of its wide use in the industry and its compatibility with the system.

- The read data will be transferred over ZigBee. Thermocouple data should be transmitted to the center at one data per minute. As the ladle will move on the forklift, its position will constantly change in the factory. By means of the mesh topology arranged in accordance with the layout, the temperature data read by the thermocouple will be transmitted to the center without interruption. Since long distances are targeted in data transmission, $868 \mathrm{MHz}$ frequency is appropriate to use.

- The amount of metal taken from the melting furnace must be measured. It is appropriate to use weight-measuring electronic forks by revising the forks of forklifts carrying the crucibles. The use of industrial products has been determined as a more practical solution than revising forklift forks with load cells.

- The amount of metal fed to the casting bench must be recorded along with the temperature and time stamp.

- By knowing the amount of metal given to the casting bench, the amount of metal in the casting bench can be calculated instantly. The calculation must be made taking into account the wheel volume. The number of wheels produced must be multiplied by the wheel weight and subtracted from the amount of metal given. In this way, the remaining amount of metal will be obtained.

- If the remaining metal level falls below the specified value in the casting bench, a warning message must be sent to melting furnace, casting bench and forklift operators.

- The temperature of the metal taken from the melting furnace must be determined and it must be provided as an input to the casting bench where the metal is supplied.

- Storing all information is critical for process optimization. The time counter starts when the "low metal level" information from the casting machine is transmitted to the center. In order to meet the metal requirement, a ladle will go to the melting furnace. The time the ladle goes to the melting furnace will be recorded. The information of the ladle that reaches the melting furnace will be collected as described in the articles above. The data collected from every point of the system is very important in determining the performance of the system and eliminating the detected bottlenecks. 


\section{Conclusion}

Within the scope of the study, a detailed literature review on ladle tracking systems has been done. Advantageous aspects of existing systems were combined in a project and additional improvements were made on existing systems. It is aimed to equip the foundry of the factory that produces an aluminum alloy passenger car wheel, with a sensor network. The working logic and main components of the system have been determined. After the system is engaged, the data collection phase will be carried out. Nonvalue-added times will be determined, financial gain, process stabilization, planning capability, predictability, risk management skill and quality gain will be provided.

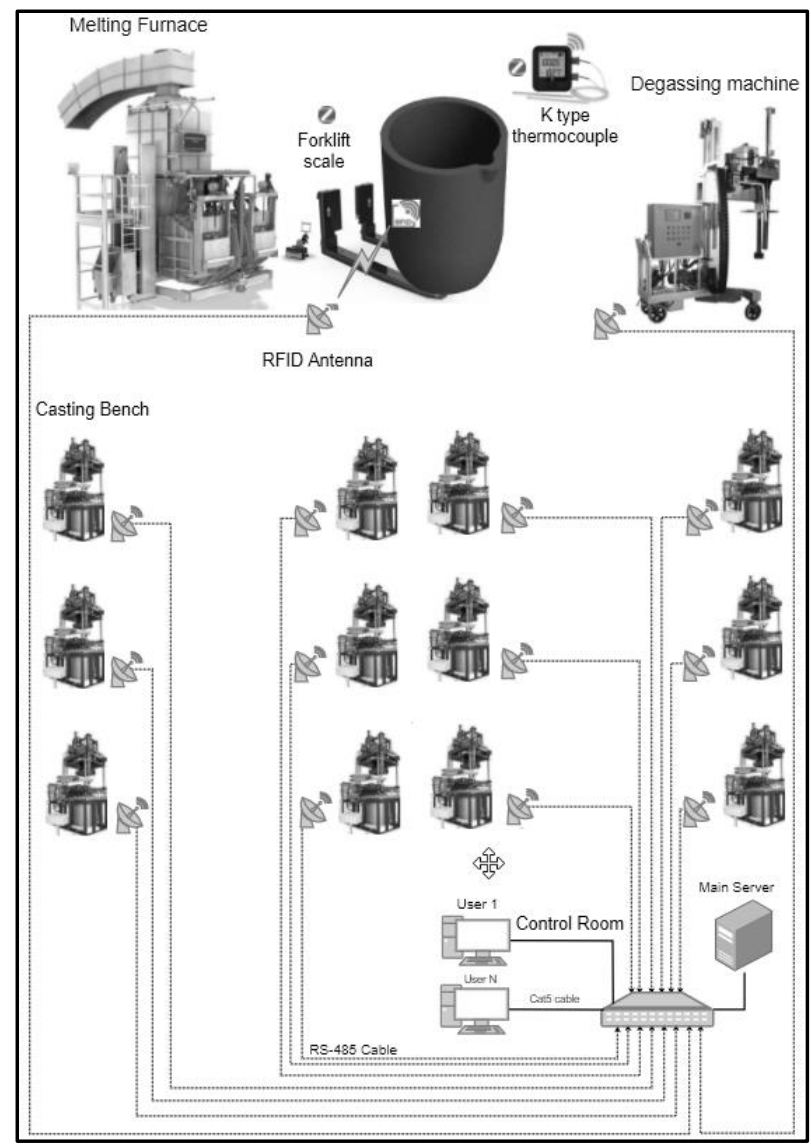

Figure 6. System Overview

\section{References}

Ahualli, J. F., Sagasti, J., G., Meyer, S., Memoli, F. (2014). Physical Ladle Tracking, AISTech Conference Proceedings, 66-158.

Dogan, H., Çaglar, M. F., Yavuz, M., and Gözel, M. A. (2016). Use of radio frequency identification systems on animal monitoring. SDU Int. J. Technol. Sci, 8, 38-53.

Guarese, G.B., Sieben, F.G., Webber, T., Dillenburg, M.R. and Marcon, C. (2012). November. Exploiting Modbus protocol in wired and wireless multilevel communication architecture. Brazilian Symposium on Computing System Engineering 13-18.
Işık, M. (2019). Alüminyum Alaşımlı Binek Araç Jantlarının Dinamik Viraj Yorulması Davranışının Deneysel ve Sayısal Olarak İncelenmesi, Master's Degree Thesis, Dokuz Eylül University, Departmant of Mechanics, 80.

Özcan, C. (2019). Lojistik Alanlarında RFID Sisteminin İşletmelerde Uygulama Olanakları ve Avantajları: İzmir İlinde Bir Uygulama, Institute of Social Sciences, Department of Business Administration, International Business Program

Parkash, D., Kundu, T. and Kaur, P. (2012). The RFID technology and its applications: a review. International Journal of Electronics, Communication \& Instrumentation Engineering Research and Development (IJECIERD), 2(3), 109-120.

Safaric, S. and Malaric, K. (2006). June. ZigBee wireless standard. In Proceedings ELMAR, 259-262.

Singh, R., Kumar, A., Ranjan, R. and Singh, G. (2020). Digitalization to drive quality: the synergy between ladle tracking system and prediction models. Ironmaking \& Steelmaking, 47(7), 814-820.

Termokupllar ile ilgili genel bilgiler. (n.d.). Elimko. Retrieved March 1, 2021, from

https://elimko.com.tr/files/TermokupllarGenelBilgiler.pdf (Int Ref. 3).

Tips for success in Using RS-485 data communications. (n.d.). BB SmartWorks. Retrieved March 1, 2021, from https://bbelec.com/Learning-Center/All-White-Papers/Serial/RS-485Tips,-Tricks,-Questions-

Answers.aspx\#: :text=A $\% 3 \mathrm{~A} \% 20 \mathrm{~A} \% 20$ standard $\% 20 \mathrm{RS} \% 2$ D485,32\%20nodes\%20to\%20be\%20connected (Int Ref. 1).

Urrea, C., Morales, C. and Kern, J. (2016). Implementation of error detection and correction in the Modbus-RTU serial protocol. International Journal of Critical Infrastructure Protection, 15, 27-37.

Watkins, M., D., Hugget., T., V., Martt, F., J. (1988). Ladle Transfer Car with Weighing System, Patent Number:4887551, Date of Patent: Nov. 7, 1989

Wu, C., Xiong, L. and Cao, R. (2018). May. Research on molten iron ladles location method based on the combination of ZigBee and image. 13th IEEE Conference on Industrial Electronics and Applications (ICIEA) 36-41.

Zhou, J., Niu, D., Li, Q. and Liu, J. (2019). Iron and steel ladles tracking management system based on RFID and WLAN. The Journal of Engineering, (22), 8310-8314.

Zigbee end devices. (2008). ScienceDirect. Retrieved March 1, 2021, from https://www.sciencedirect.com/topics/computerscience/zigbee-end-device (Int Ref. 2). 